\title{
ПРАВОВОЕ РЕГУЛИРОВАНИЕ ЗАЩИТЫ ДЕТЕЙ ВО ВРЕМЯ ВООРУЖЕННЫХ КОНФЛИКТОВ.
}

\author{
В. В. А ле ши н
}

Со времени второй мировой войны международное сообщество явилось свидетелем новьх видов конфликтов. Стали более совершенными средства и методы ведения войны. Чаше возникают конфликты, в которых регулярным вооруженным силам противостоят вооруженные отряды оппозиции. Такие боевые действия сопровождаются значительными потерями среди гражданского населения, включая детей. На дипломатической конференции в 1977 году были приняты два Дополнительных протокола к Женевским конвенциям. Эти документы значительно усовершенствовали защиту гражданского населения.

Международное гуманитарное право предусматривает общую защиту детей как лиц, не принимающих участия в военных действиях, и особую защиту - как наиболее уязвимых лиц.

Общая зацита. Во время мехдународного вооруженного конфликта дети входят в категорию лиц, которые находятся под защитой Женевской конвенции о зашите гражданского населения во время войны 1949 года (IV Женевская конвенция ). В соответствии с нормами этой конвенции маленькие граждане подпадают под действие всех положений, закрепляющих обращение с покровительствуемыми лицами. Данные положения, направленные на соблюдение принципа гуманного обращения с людьми, включающий уважение к жизни, чести, физическую и психическую неприкосновенность, запрещают пьтки, телесные наказания и обеспечивают соблюдение общепринятых юридических гарантий. Более того, дети, как часть гражданского населения, подпадают под действие норм международного гуманитарного права, относящихся к ведению войны. Эти положения, которые предусматривают необходимость проведения различия между гражданскими лицами и комбатантами и запрещают нападение на грахданское население, закреплены в I Дополнительном протоколе, касающемся защиты жертв вооруженньх конфликтов международного характера 1977 года, к Женевским конвенциям 1949 года (Протокол I).

Известно, что во время войны грахданское население и

* Кандидат юридических наук 
комбатанты не всегда строго отделены друг от друга, а поток беженцев, состояший из детей, женшин, пожилых людей, смешивается с отступаюшими в беспорядке войсками. ${ }^{1}$ В этой связи пункт 3 статьи 50 Протокола I указывает на то, что присутствие среди гражданского населения отдельных лищ, не подпадаюших под определение гражданских лиц, не лишает это население его гражданского характера, а пункт 1 статьи 51 закрепляет положение, в соответствии с которым гражданское население и отдельные лича пользуются общей зашитой от опасностей, возникаюших в связи с военными операциями.

В вооруженньх конфликтах немеждународного характера дети находятся под защитой основньх гарантий, касаюшихся обрашения с лицами, не принимаюшими участия в военных действиях, и закрепленных в статъе 3, общей для всех четырех Женевских конвенций. Положениями данной статьи запрещаются посягательства на жизнь, человеческое достоинство, применение пыток, взятие заложников, осуждение и применение наказания без предварительного судебного разбирательства. Кроме того, II Дополнительный протокол, касающийся защиты жертв вооруженных конфликтов немеждународного характера 1977 года, к Женевским конвенциям 1949 года (Протокол II ) кодифицирует принципы, в соответствии с которыми население и отдельные гражданские лица не должны рассматриваться в качестве объекта военного нападения.

Особая защита. Несмотря на то, что IV Женевская конвеншия содержит многочисленные положения о защите детей, приншип, на основании которого дети пользуются особой зашитой, в ней четко закреплен не был. Сушествуюший пробел был заполнен статьей 77 Протокола I, где указывается, что дети пользуются особым уважением, и им обеспечивается защита от любого рода непристойньх посягательств. На стороны, находящиеся в конфликте, возложена обязанность обеспечивать им защиту и помошь, которые требуются с учетом возраста или по любой другой причине. Таким образом, в Протоколе I закреплен принцип особой защиты детей во время вооруженного конфликта международного характера.

К вооруженным конфликтам немеждународного характера применима статья 4 Протокола II. В этой статье, озаглавленной "Основные гарантии", содержится пункт, посвященный исключительно детям. Он утверждает, что детям обеспечиваются нсобходимые забота и помощь (пункт 3 статьи 4). Затем в этой статье перечисляются относящисся к детям специальные меры, которыс конкретизируют изложеннос выше общее правило. Построснис статьи 4 показывает насколько важным считали авторы Прото- 
кола II защиту детей во время вооруженного конфликта немеждународного характера и дает нам право утверждать, что принцип особой зашиты детей во время внутренних конфликтов этой статьей установлен. ${ }^{2}$

Согласно выводам одного из исследований ЮНЕСКО по вопросу о детях и войне, положения международного гуманитарного права, имеющие целью сохранения целостности семьи во время вооруженных конфликтов имеют особое значение. В этом исследовании говорится: Когда мы изучаем характер психологической травмы, полученной ребенком, ставшем жертвой войны, мы обнаруживаем, что эмоционально на него не очень воздействуют такие проявления войны как бомбежки и военные операции. Влияние внешних событий на семейные связи и отрыв от обычного образа жизни - вот что воздействует на ребенка, а больше всего - разлука с матерью ${ }^{3}$.

Во Всеобщей декларации прав человека 1948 года провозглашается: "Семья является естественной и основной ячейкой общества и имеет право на защиту со стороны общества и государства". Международный пакт о гражданских и политических правах 1966 года ( статьи 23 и 24 ) и Международный пакт об экономических, социальньх и культурньх правах 1966 года (статья 10), закрепляют нормы, регулирующие особую защиту и заботу о рсбенке. Положения указанных документов детализированы в Женевских конвенциях и Дополнительньх протоколах.

IV Женевская конвенция закрепляет нормы в соответствии с которыми интернированные члены одной семьи должны содержаться в одном помещении, отдельно от других интернированных. Им должны быть предоставлены необходимые условия для ведения нормальной семейной жизни. Более того, интернированные могут потребовать, чтобы их дети, оставшиеся без родительского попечения, были интернированы вместе с ними. Однако это правило может быть ограничено по причинам, связанным , например, с отдельными заболеваниями родителей или детей, исполнением решений судебньг органов и Т.д. , но эти ограничения должны соответствовать действующим законам и могут быть обжалованы. заинтересованными сторонами в судебном порядке. Протоколы I и II устанавливают обязанность воюющих способствовать воссоединению семей.

Значительная правовая гарантия, адресованная матери и ребенку закреплена статьей 76 Протокола I. В соответствии с ее положениями женщины пользуются особым уважением, им обеспечивается защита от различного рода посягательств. Дела арестованньх, задержанньх или интернированньх матерей малолетних детей, беременньх женщин рассматриваются в пер- 
воочередном порядке. Смертньй приговор в отношения их в исполнение не приводится. Отметим также, что положения Протокола I об арестованных, задержанных или интернированных матерях, имеющих зависяших от них детей, исходят из необходимости содержания матери и ребенка вместе. К сожалению Протокол II не содержит аналогичных норм, что является его существенной недоработкой.

Важное место в международном гуманитарном праве занимают вопросы соблюдения прав ребенка при временной эвакуации в период вооруженного конфликта. Эвакуация должна отвечать требованиям, закрепленным в статье 78 Протокола I. Временная эвакуация может быть осуществлена только по неотложным причинам, которые связаны с состоянием здоровья или лечением детей, а также по соображениям безопасности. Под безопасностью детей во время вооруженного конфликта следует понимать состояние зашищенности ребенка от внутренних и внешних утроз. Когда должное состояние защищенности детей обеспечено быть не может, решается вопрос об их временной эвакуации. На эвакуацию требуется обязательное письменное согласие родителей или законных опекунов. Если они не могут быть найдены, требуется письменное согласие на эвакуацию от лиц, которые по закону или обычаю несут главную ответственность за попечение над детьми. Ими могут быть главные врачи больниц, санаториев, директора интернатов, заведуюшие детскими садами, главные тренеры или администраторы спортивных лагерей, а также дееспособные родственники, которые на период эвакуации не являлись их законньми опекунами. Такая эвакуация проводится под наблюдением Державы-Покровительницы по согласованию с заинтересованными сторонами. Сроки временной эвакуации в документе не закреплены. Однако по смыслу рассматриваемой статьи временная эвакуация должна быть непрерывной, заканчиваться по окончании боевых действий и восстановления конституционного порядка. В целях избежания различных конфликтных ситуаџий, которые могут возникнуть в период отправления детей, нахохдения их на территории другого государства, возвращения домой, заинтересованньм сторонам эти вопросы следует урегулировать нормативно. В целях облегчения возвращения в свои семъи и страну на кахдого ребенка заполняется карточка (если это не нанесет ребенку ущерб). Карточки направляются в Центральное справочное агентство MKKK. Если же такие карточки заполнить и передать в МKKK не представилось возможньм, то следует руководствоваться статьей 24 IV Женевской конвенции. Эта статья ориентирует государства на обеспечение детей опознавательными медальонами 
или использование любьх друтих способов, которые должны способствовать установлению личности детей в возрасте до 12 лет. Среди любых других способов видимо могут быть вышитые яркими нитками, написанные краской установочные данные на костюмчике ребенка, передача лично родителями или с использованием средств связи в государство, где находится ребенок, его данных, сведений о привычках, особенностях и любой другой информации, которая обеспечит безопасность ребенка, воссоединение семьи, прольет свет на материнское и отцовское счастье от обшения со своим самым лучшим ребенком.

В случае вооруженных конфликтов немеждународного характера Протокол II предусматривает эвакуацию детей из района военных действий в более безопасный район внутри страны. Такая работа всегда связана с решением ряда административных задач - обеспечение жильем, питанием, медицинским обслуживанием. Дети должны продолжать учебу, получать сведения о судьбе родителей, другую информацию и т.д. Поставленные задачи могут оперативно решаться в тесном сотрудничестве с сотрудниками MKKK, у которьх имеется немальй опьт аналогичной работы.

Важным и актуальным вопросом любой войны является участие в боевьх действиях детей, так как не допустить этого практически невозможно. В такой кризисной ситуации дети не только будут во всем помогать своим родителям, сражающимся с оружием в руках, но и направлять все свои детские усилия, чтобы быть похожими на них. Возрастной критерий участия в военных действиях закреплен двумя Дополнительными протоколами. Этими важными документами устанавливается, что дети, не достигшие пятнадцатилетнего возраста, не подлежат вербовке в вооруженные силы. Однако Протокол I указывает, что такие лица не должны принимать непосредственное участие в военньх действиях. Нормы Протокола II более категоричны и закрепляют требование о том, что детям, не достигшим пятнадцатилетнего возраста, не разрешается принимать участия в военньх действиях.

Таким образом, Протокол II закрепляет полный и абсолютный запрет на участие в военных действиях детей, не достигших возраста пятнадцати лет. Этот запрет распространяется на прямое (нспосредственное) участие в боевых действиях с оружием в руках и опосредованное (косвенное) участие в войне, т.е. проведение разведки местности, сбор и передачу информации, оказание технической помощи, проведение подрывной деятельности . Такой запрет, налагаемый данным протоколом на государства является более суровым, по сравнению с ситуациями, связанными с международным вооруженным конфликтом. 
При формировании воинских подразделений из числа лиц, достигших пятнадцатилетнего возраста, но которым еше не исполнилось восемнадцати лет, Протокол I ориентирует государства на первоочередное внимание к лицам более старшего возраста.

Если, несмотря на запрет, содержашийся в пункте 2 статьи 77 Протокола I дети, не достигшие пятнадцати лет, были зачислены в вооруженные силы, то они рассматриваются как комбатанты и при захвате в плен имеют статус военнопленных. Кроме того, при нахождении в плену они пользуются особой защитой в рамках международного гуманитарного права. Нормы Протокола I адресованы сторонам, находяшимся в конфликте, а не детям, участие которьх в военньх действиях не является нарушением ими законов. ${ }^{4}$

Детям, свобода которых ограничена по причинам, связанным с вооруженным конфликтом немеждународного характера, не достигшим возраста пятнадцати лет, предоставляется особая защита ( пункт 3 d статьи 4 Протокола II ). Однако данная норма не отвечает тем общественным отношениям, которые существуют в мире в условиях внутренних вооруженных конфликтов. Речь идет о необходимости детальной и четкой регламентации правового положения детей, задержанньх в качестве участников отрядов вооруженной оппозиции и не доститших возраста пятнадцати лет.

Значительным шагом в развитии международного гуманитарного права являются положения IV Женевской конвенции, двух протоколов, которые четко закрепили возрастной критерий - восемнадцать лет, ниже которого смертный приговор не может быть приведен в исполнение. Этот возраст - абсолютный предел, ниже которого смертный приговор не может быть вынесен, даже если имеются все другие условия, которые делают применимым такой приговор. ${ }^{5}$

Проблема защиты детей в период вооруженных конфликтов в настояшее время является актуальной. События в России (Чечне), Югославии, Таджикистане, Афганистане и других районах вооруженных противостояний убедительно показали, что самая незащищенная и бесправная категория лиц в период боевых действий - дети. Болезни, психологические и физические травмы, боль и скорбь от разлуки или потери родителей и близких, голод, нищета, испуг, неверие в справедливость сопровождают ребенка в таких кризисных ситуациях.

Многочисленные положения международного гуманитарного права устанавливают и развивают принцип особой защиты детей во время вооруженных конфликтов. Данные нормы должны 
неукоснительно соблюдаться воюющими сторонами, потому что под угрозой наше будущее - дети.

1 См.:альсховен $Ф$. Ограничение методов и средств ведения войны. MKKK, 1994. - С. 118.

2 Платтнер Д. Дети и война // Защита детей в международном гуманитарном праве. - MKKK, 1995. - С. 8.

3 См. Там же. - С. 9 - 10 .

4 Дутли М.Т. Дети и война // Дети - комбатанты, захваченные в плен // MKKK, 1995, - C. 71.

5 Пиаттнер Д. Указ. соч. - С. 16.

\title{
ПРОБЛЕМЫ ИМПЛЕМЕНТАЩИИ НОРМ МЕЖДУНАРОДНОГО УГОЛОВНОГО ПРАВА В РОССИЙСКОМ УГОЛОВНОМ ЗАКОНОДАТЕЛЬСТВЕ
}

\author{
А.Х. М а в лон о в $^{*}$, А.Б. $\mathrm{M}$ е 3 я е B** $^{* *}$
}

Как известно, с 1 января 1997 года вступил в силу новый Уголовньй Кодекс России. В нем впервые выделены в отдельную главу так называемые "международные преступления". Глава 34 УК РФ озаглавлена "Преступления против мира и безопасности человечества" и вкпючает в себя 8 составов преступлений, кажды из которьх является актом имплементации в российском утоловном законодательстве норм международного права. Часть составов (например, статьи $353,354,356$ ) уже были имплементированы в усеченном виде в УК РСФСР 1960 года, а часть (например, статьи $357,358,359$ ) - впервые включаются в российский уголовный кодекс. Приветствуя, в целом, сам факт реализации международного права в новом УК России, нам бы хотелось обратить внимание на ряд серьезных проблем, касающихся качества этой имплементации.

\section{1. АГРЕССИЯ}

Первые две статьи рассматриваемой главы посвящены уголовному преследованию агрессии - ст.353 - за планирование, подготовку, развязывание или ведение агрессивной войны, и

- Член Российской Ассоциации Международного права. Спискатель кафедры международного права Казанского Государственного Универснтета

** Старший преподаватель кафедры конституционного и международного права Татарстанского института содействия бнзнесу (г. Казань). 